\title{
Soil Microbial Responses to 28 Years of Nutrient Fertilization in a Subarctic Heath
}

\author{
Lettice C. Hicks, ${ }^{1 *} \odot$ Kathrin Rousk,${ }^{2,3}$ Riikka Rinnan, ${ }^{2,3}$ and \\ Johannes Rousk ${ }^{1}$
}

\begin{abstract}
${ }^{1}$ Section of Microbial Ecology, Department of Biology, Lund University, Ecology Building, 22362 Lund, Sweden; ${ }^{2}$ Terrestrial Ecology Section, Department of Biology, University of Copenhagen, Universitetsparken 15, 2100 Copenhagen, Denmark; ${ }^{3}$ Centre for Permafrost (CENPERM), University of Copenhagen, Øster Voldgade 10, 1350 Copenhagen, Denmark
\end{abstract}

\begin{abstract}
Arctic and subarctic soils are typically characterized by low nitrogen $(\mathrm{N})$ availability, suggesting $\mathrm{N}$-limitation of plants and soil microorganisms. Climate warming will stimulate the decomposition of organic matter, resulting in an increase in soil nutrient availability. However, it remains unclear how soil microorganisms in $\mathrm{N}$-limited soils will respond, as the direct effect of inorganic $\mathrm{N}$ addition is often shown to inhibit microbial activity, while elevated $\mathrm{N}$ availability may have a positive effect on microorganisms indirectly, due to a stimulation of plant productivity. Here we used soils from a longterm fertilization experiment in the Subarctic (28 years at the time of sampling) to investigate the net effects of chronic $\mathrm{N}$-fertilization $\left(100 \mathrm{~kg} \mathrm{~N} \mathrm{ha}^{-1}\right.$ $\mathrm{y}^{-1}$, added together with $26 \mathrm{~kg} \mathrm{P}$ and $90 \mathrm{~kg} \mathrm{~K} \mathrm{ha}^{-1} \mathrm{y}^{-1}$, as expected secondary limiting nutrients for plants) on microbial growth, soil C and $\mathrm{N}$ mineralization, microbial biomass, and community structure. Despite high levels of longterm fertilization, which significantly increased
\end{abstract}

Received 23 June 2019; accepted 24 October 2019;

published online 14 November 2019

Electronic supplementary material: The online version of this article (https://doi.org/10.1007/s10021-019-00458-7) contains supplementary material, which is available to authorized users.

Author Contributions JR and KR designed the study and conducted the soil sampling. RR provided the $\mathrm{CO}_{2}$-flux field-data. JR performed the laboratory analyses. LCH analyzed the data and wrote the manuscript, with contributions from all authors.

*Corresponding author; e-mail: lettice.hicks@biol.lu.se primary production, we observed relatively minor effects on soil microbial activity. Bacterial growth exhibited the most pronounced response to longterm fertilization, with higher rates of growth in fertilized soils, whereas fungal growth remained unaffected. Rates of basal soil $\mathrm{C}$ and $\mathrm{N}$ mineralization were only marginally higher in fertilized soils, whereas fertilization had no significant effect on microbial biomass or microbial community structure. Overall, these findings suggest that microbial responses to long-term fertilization in these subarctic tundra soils were driven by an increased flow of labile plant-derived $\mathrm{C}$ due to stimulated plant productivity, rather than by direct fertilization effects on the microbial community or changes in soil physiochemistry.

Key words: Subarctic tundra; decomposition; biogeochemistry; microbial ecology; nitrogen cycling; bacterial and fungal growth; soil respiration; plant-soil interactions; nutrient fertilization.

\section{HighLIGHTS}

- High levels of chronic fertilization had minor effects on soil microbial activity

- Fertilization increased bacterial growth but not 
fungal growth

- $\mathrm{C}$ and $\mathrm{N}$ mineralization rates were only marginally higher in fertilized soils

\section{INTRODUCTION}

Arctic and subarctic ecosystems are often characterized by low nutrient availability, due to low temperatures, which slow rates of organic matter decomposition (Hobbie 1996). Nitrogen (N) availability, in particular, is usually found to be most limiting in these systems, with evidence for $\mathrm{N}$ limitation reported for both plants (Shaver and Chapin 1980; Atkin 1996) and soil microorganisms (Weintraub and Schimel 2003; Sistla and others 2012). The availability of inorganic nutrients-including $\mathrm{N}$-in soils is expected to increase, due to an acceleration of mineralization rates in response to climate warming (Jenny 1980; Hobbie and others 2002; Mack and others 2004). However, rather than relieving nutrient limitation and increasing microbial activity, the addition of inorganic $\mathrm{N}$ is often found to reduce microbial growth and respiration (Ramirez and others 2010; Rousk and others 2011; Kristensen and others 2018). This suggests that increased inorganic $\mathrm{N}$ availability can inhibit soil microbial activities (see reviews by Fog 1988; Treseder 2008; Pregitzer and others 2008; Whalen and others 2018). In contrast, increased $\mathrm{N}$ availability might have a positive effect on soil microorganisms indirectly, via stimulation of plant productivity which in turn provides organic matter to fuel microbial activity (Wardle 2002; Mack and others 2004).

In arctic and subarctic ecosystems, $\mathrm{N}$-fertilization (either with $\mathrm{N}$ added alone, or together with $\mathrm{P}$ and/ or $\mathrm{K}$, as expected secondary limiting nutrients for plant growth) has often been shown to increase plant productivity and standing plant biomass (Graglia and others 2001; Gough and others 2002; Mack and others 2004; Van Wijk and others 2003; Ravn and others 2017), resulting in increased plant inputs to soil (Johnson and others 2000). In Alaskan tussock tundra systems, fertilization also induced a clear shift in plant composition, with a shift toward shrubs in an acidic tundra site and a shift toward graminoids and forbs in a non-acidic tundra site (Gough and Hobbie 2003; McLaren and Buckeridge 2019). In a non-acidic Swedish subarctic heath, despite an increase in the total abundance of vascular plants with fertilization, there were only minor shifts in the relative abundance of different plant functional types (Van Wijk and others 2003).
In contrast to the consistent effect of enhanced plant productivity in high-latitude ecosystems in response to fertilization, the effect on soil microbial biomass is less clear, in part because there have been very few assessments of long-term responses. In short-term studies $(<5$ years) microbial $\mathrm{N}$ has typically been found to be higher with $\mathrm{N}$-fertilization, with no effect on microbial biomass C (Jonasson and others 1999a; Buckeridge and others 2010; Churchland and others 2010). In long-term studies of Alaskan tundra soils, after 16 and 26 years of fertilization, there were also no effects of $\mathrm{N}$-fertilization on microbial biomass $\mathrm{C}$, and $\mathrm{N}$ fertilization even reduced microbial biomass $\mathrm{N}$ at one site (McLaren and Buckeridge 2019). In contrast, in a long-term study in a Swedish subarctic heath, after 15 years of fertilization, microbial PLFAs were significantly higher in fertilized soils (Rinnan and others 2007), an effect that became even more pronounced after 18 years (Rinnan and others 2013). In this case, it was suggested that the effect of fertilization on microbial biomass may increase over time, following the trajectory of increases in plant productivity (Rinnan and others 2013). However, this requires further verification.

Despite the inconsistent effects of fertilization on microbial biomass, there is evidence that fertilization can affect microbial activity. In an Alaskan arctic tundra system, although plant productivity doubled with fertilization, soil $\mathrm{C}$ and $\mathrm{N}$ stocks decreased, indicating increased turnover of soil organic matter (Mack and others 2004). Similarly, in the Swedish Subarctic, measurements of soil respiration in the field were $133 \%$ higher for fertilized than control treatments, suggesting an acceleration of C cycling with fertilization (Ravn and others 2017). Together, these studies suggest that elevated $\mathrm{N}$ availability can have a profound effect on biogeochemical cycling belowground.

Although rates of soil $\mathrm{C}$ and $\mathrm{N}$ mineralization are often assumed to be coupled (Hart and others 1994), recent studies have shown that this is not always the case, particularly in $\mathrm{N}$-poor soils (Rousk and others 2016; Ehtesham and Bengtson 2017; Kristensen and others 2018). Schimel and Bennett (2004) suggested that in N-poor ecosystems, depolymerization of $\mathrm{N}$-containing compounds by extracellular enzymes is rate-limiting in the production of bioavailable $\mathrm{N}$. If $\mathrm{N}$ availability increases, however, microorganisms may be able to increase the synthesis of $\mathrm{N}$-acquisitioning enzymes (Weintraub and Schimel 2003; Sistla and others 2012), resulting in enhanced rates of $\mathrm{N}$ depolymerization and mineralization (Wild and others 2015). A recent study of subarctic forest soils found some 
support for this theory, as increased $\mathrm{N}$ availability reduced the $\mathrm{C} / \mathrm{N}$ ratio of mineralization, suggesting that microbial use of organic matter shifted to components richer in $\mathrm{N}$ (Kristensen and others 2018). The $\mathrm{N}$ mineralization potential in Canadian arctic tundra soils was positively correlated with ammonium and dissolved organic $\mathrm{N}$ concentrations, and negatively correlated with the soil $\mathrm{C} / \mathrm{N}$ ratio (Chu and Grogan 2010). This also validates the expectation that $\mathrm{N}$ availability will be an important determinant of $\mathrm{N}$ mineralization in $\mathrm{N}$ poor arctic and subarctic soils.

Here we used soils from a long-term (28 years at the time of sampling) nutrient fertilization experiment in the Swedish Subarctic (Michelsen and others 1996), to investigate the effect of long-term elevated $\mathrm{N}$ availability on microbial growth and soil $\mathrm{C}$ and $\mathrm{N}$ mineralization rates. Owing to the documented sustained increase in plant productivity with chronic fertilization at the experimental site (see Jonasson and others 1999a; Graglia and others 2001; Illeris and others 2004; Campioli and others 2012; Ravn and others 2017), we hypothesized that the increase in plant-derived $C$ inputs to soil with fertilization would result in (1) higher rates of microbial growth. We also hypothesized that fertilization would (2) increase rates of organic matter mineralization, with $\mathrm{N}$ mineralization expected to increase more than $\mathrm{C}$ mineralization (Schimel and Bennett, 2004), resulting in a decrease in the $\mathrm{C} / \mathrm{N}$ ratio of mineralization. In addition to microbial process rates, we also measured microbial biomass, reflecting the recent history of microbial growth (that is, biomass production) in the soils. As such, we hypothesized that (3) microbial biomass would be higher in fertilized soils, due to a history of higher rates of microbial growth (see hypothesis 1 above), and that the effect size would be larger than measured in earlier assessments at the site (Rinnan and others 2007, 2013) if microbial biomass followed the trajectory of increased plant productivity in fertilized soils over time.

\section{Materials ANd Methods}

\section{Study Site and Field Experiment}

The experimental site is a tundra heath, located just above the treeline $(450 \mathrm{~m}$ above sea level) near Abisko in northern Sweden $\left(68^{\circ} 19^{\prime} \mathrm{N}, 18^{\circ} 15^{\prime} \mathrm{E}\right)$. The mean annual temperature is $0.2^{\circ} \mathrm{C}$ and the annual precipitation is $340 \mathrm{~mm}$ (30-year mean 1986-2015; Abisko Scientific Research Station, 2016), with the growing season lasting from June to early September. Vegetation is dominated by the dwarf shrub Cassiope tetragona, which accounts for approximately one-third of aboveground biomass (Michelsen and others 1996). Other low or dwarf shrubs present include Empetrum hermaphroditum, Vaccinium uliginosum, Rhododendron lapponicum, Salix hastata, and Betula nana (Havström and others 1993). Abundant graminoids include Calamagrostis lapponica, Poa alpigena, and Carex vaginata (Graglia and others 2001). Moss cover at the site is about $40 \%$ (Sorensen and others 2012). Soils have formed on base-rich mica schists and are classed as Histosols (according to the IUSS Working Group World Reference Base for soils 2006), whereby the

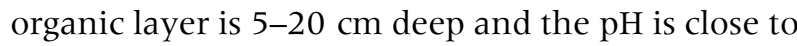
neutral (Table 1).

Experimental treatments to investigate the direct and indirect effects of climatic warming were established at the site in 1989. Here we used soils from the fertilization field treatment, whereby inorganic $\mathrm{N}$ together with $\mathrm{P}$ and $\mathrm{K}$ (as expected secondary limiting nutrients for plant growth) have been added to six replicated plots of $1.2 \mathrm{~m} \times 1.2 \mathrm{~m}$ in June each year since 1989 (except in 1993 and 1998). Fertilizer loads equivalent to $100 \mathrm{~kg} \mathrm{~N} \mathrm{ha}^{-1}$, $26 \mathrm{~kg} \mathrm{P} \mathrm{ha}{ }^{-1}$ and $90 \mathrm{~kg} \mathrm{~K} \mathrm{ha}^{-1}$, were added annually in the form of $\mathrm{NH}_{4} \mathrm{NO}_{3}, \mathrm{KH}_{2} \mathrm{PO}_{4}$, and $\mathrm{KCl}$, respectively. The $\mathrm{N}$ application was considered to reflect the magnitude of potential $\mathrm{N}$ release from the soil of tundra ecosystems due to enhanced mineralization rates under a climate warming scenario (Mack and others 2004) and has had no effect on soil $\mathrm{pH}$ (Table 1). Six additional replicated plots of the same size, but without nutrient amendments, served as a control.

\section{$\mathrm{CO}_{2}$ Exchange}

$\mathrm{CO}_{2}$ fluxes were measured at three time points in June-July 2014, when the fertilization treatment had been active for 26 years, using an EGM-4 Environmental Gas Monitor (PP Systems, Hitchin, UK) with a sensor probe type 3. During measurements, a transparent polycarbonate chamber was placed on a permanently installed aluminum frame $(21.4 \times 21.4 \mathrm{~cm})$ that extended to $10 \mathrm{~cm}$ depth in soil in each plot. The chamber headspace, which was well mixed with a fan, was sealed air-tight by adding water to a groove of the aluminum frame, and $\mathrm{CO}_{2}$ concentration inside the chamber was monitored. First, net ecosystem exchange (NEE) was measured for $5 \mathrm{~min}$, followed by lifting the chamber to return to ambient $\mathrm{CO}_{2}$ concentration, and then ecosystem respiration $\left(E_{\mathrm{R}}\right)$ was measured after darkening the chamber with a black cloth. NEE and $E_{R}$ were calculated from the linear change 
Table 1. Physiochemical and Soil Microbial Properties of Control and Fertilized Soils Sampled from a LongTerm Nutrient (NPK) Addition Experiment in Northern Sweden.

\begin{tabular}{lcc}
\hline & Control & Fertilized \\
\hline Water content $\left(\mathrm{g} \mathrm{H}_{2} \mathrm{O} \mathrm{g}^{-1} \mathrm{dwt}\right)$ & $2.0 \pm 0.2$ & $2.0 \pm 0.2$ \\
Soil organic matter $\left(\mathrm{g} \mathrm{g}^{-1} \mathrm{dwt}\right)$ & $0.61 \pm 0.05$ & $0.59 \pm 0.05$ \\
$\mathrm{pH}$ & $6.8 \pm 0.3$ & $6.7 \pm 0.2$ \\
$\mathrm{NH}_{4}^{+}\left(\mu \mathrm{g} \mathrm{g} \mathrm{g}^{-1} \mathrm{SOM}\right)$ & $9.2 \pm 0.9$ & $12.0 \pm 3.4$ \\
$\mathrm{NO}_{3}^{-}\left(\mu \mathrm{N} \mathrm{g}^{-1} \mathrm{SOM}\right)$ & $7.1 \pm 1.0$ & $7.5 \pm 1.5$ \\
$\mathrm{Microbial} \mathrm{biomass}\left(\mathrm{mg} \mathrm{C} \mathrm{g}^{-1} \mathrm{SOM}\right)$ & $5.8 \pm 0.5$ & $7.0 \pm 0.4$ \\
Ergosterol $\left(\mu \mathrm{\mu g} \mathrm{g}^{-1} \mathrm{SOM}\right)$ & $204 \pm 13$ & $205 \pm 6$ \\
& & \\
\hline Data represent mean \pm ISE $(n=6)$. & & \\
\hline
\end{tabular}

in headspace $\mathrm{CO}_{2}$ concentration, and gross ecosystem productivity (GEP) was estimated as $\mathrm{NEE}+E_{\mathrm{R}}$.

\section{Soil Sampling}

Soils were sampled in July 2016, after the fertilization treatment had been active for 28 years. Soil samples were collected from 6 to 8 randomized cores $(2 \mathrm{~cm}$ diameter) from each plot, including only the O-horizon to a depth of about $5 \mathrm{~cm}$. After removing stones and visible roots, soils from each plot were sieved, resulting in 12 independent samples (2 field treatments $\times 6$ replicates). The soils were stored at $4^{\circ} \mathrm{C}$ in gas-permeable bags until assessment, which occurred within 10 days of sampling.

\section{Soil Physiochemistry}

Soil subsamples were used to measure gravimetric soil moisture content $\left(105^{\circ} \mathrm{C}\right.$ for $\left.24 \mathrm{~h}\right)$ and soil organic matter (SOM) content through loss on ignition $\left(600^{\circ} \mathrm{C}\right.$ for $\left.12 \mathrm{~h}\right)$. Soil $\mathrm{pH}$ was measured in a $1: 5(\mathrm{w}: \mathrm{V})$ water extraction using an electrode. The concentration of $\mathrm{NH}_{4}^{+}$and $\mathrm{NO}_{3}^{-}$was determined in diffusion traps in a $1 \mathrm{M} \mathrm{KCl}$ soil extract (see below).

\section{Bacterial and Fungal Growth}

Bacterial growth was determined by measuring the rate of ${ }^{3} \mathrm{H}$-Leucine (Leu) incorporation in extracted bacteria (Bååth and others 2001; Rousk and others 2009). For this, $1.0 \mathrm{~g}$ fwt soil was mixed with $20 \mathrm{ml}$ demineralized water, vortexed for $3 \mathrm{~min}$ and centrifuged $(10 \mathrm{~min}$ at $1000 \mathrm{~g})$. The resulting bacterial suspension was incubated at $16^{\circ} \mathrm{C}$, with $2 \mu \mathrm{l} \mathrm{l-}$ $\left[4,5-{ }^{3} \mathrm{H}\right]$-Leucine $\left(5.7 \mathrm{TBq} \mathrm{mmol}^{-1}\right.$, PerkinElmer, USA) and unlabeled Leu with a final concentration of $275 \mathrm{nM}$ Leu in the bacterial suspension. Bacte- rial growth was terminated after $2 \mathrm{~h}$ by adding 75 $\mu \mathrm{l}$ of $100 \%$ trichloroacetic acid. Centrifugation and washing were performed as described by Bååth and others (2001). Scintillation cocktail (Ultima Gold; PerkinElmer, USA) was added and the radioactivity was measured using a liquid scintillation counter. The amount of leucine incorporated into extracted bacteria (pmol Leu incorporated $\mathrm{g}^{-1} \mathrm{SOM} \mathrm{h}^{-1}$ ) was used as a measure of bacterial growth.

Fungal growth and biomass (ergosterol concentration) were measured using the acetate-in-ergosterol incorporation method (Newell and Fallon 1991) adapted for soil (Bååth 2001; Rousk and others 2009), which estimates the rate of ergosterol synthesis as a measure of fungal growth. $0.5 \mathrm{~g}$ fwt soil was mixed with $20 \mu \mathrm{l}$ of ${ }^{14} \mathrm{C}$-acetate solution $\left(\left[1-{ }^{14} \mathrm{C}\right]\right.$ acetic acid, sodium salt, $2.07 \mathrm{GBq} \mathrm{mmol}^{-}$ 1 , PerkinElmer) and unlabeled sodium acetate, resulting in a final acetate concentration of $220 \mu \mathrm{M}$ in the soil slurry. Samples were incubated at $16^{\circ} \mathrm{C}$ for $4 \mathrm{~h}$ before growth was terminated by the addition of formalin. Ergosterol and incorporated acetate were measured according to Rousk and Bååth (2007). The amount of acetate incorporated into ergosterol ( $\mathrm{pmol} \mathrm{g}^{-1} \mathrm{SOM} \mathrm{h}^{-1}$ ) was used as a measure of fungal growth. Ergosterol concentration was estimated from the UV absorbance at $282 \mathrm{~nm}$ compared with external standards.

\section{Soil Respiration and Microbial Biomass}

Respiration was measured using $0.5 \mathrm{~g}$ fwt soil in $20-\mathrm{ml}$ glass vials. The headspace was purged with pressurized air before the vial was closed with a crimp lid. The $\mathrm{CO}_{2}$ concentration in the pressurized air was determined in empty vials and later subtracted to determine soil respiration. Vials were incubated for $24 \mathrm{~h}$ at $16^{\circ} \mathrm{C}$ before the headspace $\mathrm{CO}_{2}$ concentration was analyzed using a gas chro- 
matograph equipped with a methanizer and flame ionization detector.

Substrate induced respiration was measured as a proxy for microbial biomass. Briefly, $12 \mathrm{mg}$ 4:1 glucose/talcum was vigorously mixed into $0.5 \mathrm{~g}$ soil (corresponding to $8 \mathrm{mg}$ glucose- $\mathrm{C}^{-1}$ soil fwt). After $30 \mathrm{~min}$, vials were purged with pressurized air and incubated at $22^{\circ} \mathrm{C}$ for $2 \mathrm{~h}$ before the concentration of $\mathrm{CO}_{2}$ was determined (as described above). Substrate induced respiration was used to estimate microbial biomass $\mathrm{C}$, where $1 \mu \mathrm{g} \mathrm{CO}_{2}$ at $22^{\circ} \mathrm{C}$ corresponds to $20 \mu \mathrm{g}$ microbial biomass $\mathrm{C}$ (recalculated from Anderson and Domsch 1978).

\section{Gross N Mineralization and Nitrification}

Gross $\mathrm{N}$ mineralization (that is, ammonification) and gross nitrification rates were determined using the ${ }^{15} \mathrm{~N}$ pool dilution method, as described by Rousk and others (2016) with modifications. Briefly, two subsamples of each soil (each $5.0 \mathrm{~g}$ fwt) were weighed into $50 \mathrm{ml}$ plastic tubes, to which $115 \mu \mathrm{l} \mathrm{NH} \mathrm{N}_{4} \mathrm{Cl}\left(45 \mu \mathrm{g} \mathrm{N} \mathrm{ml}^{-1}\right.$, enriched to 1 atom $\%{ }^{15} \mathrm{~N}$ ) was administered using a pipette. Soils were immediately vigorously mixed with a spatula to ensure even distribution of the added $\mathrm{NH}_{4} \mathrm{Cl}$, before pots were lidded. Soil $\mathrm{NH}_{4}{ }^{+}$and $\mathrm{NO}_{3}{ }^{-}$were extracted using $1 \mathrm{M} \mathrm{KCl}$ solution. One set of subsamples was extracted approximately $\mathrm{l} \mathrm{h}$ after ${ }^{15} \mathrm{~N}$ addition, and the second set was treated identically after $16 \mathrm{~h}$ incubation at $16{ }^{\circ} \mathrm{C}$ without light. $\mathrm{NH}_{4}{ }^{+}$ and $\mathrm{NO}_{3}{ }^{-}$were isolated from the extract by diffusion to acidified glass fiber traps, according to standard procedures (IAEA 2001). The amount of $\mathrm{NH}_{4}{ }^{+}-\mathrm{N}$ and $\mathrm{NO}_{3}{ }^{-}-\mathrm{N}$ was determined by isotoperatio mass spectrometry (IRMS), and the ${ }^{15} \mathrm{~N} /{ }^{14} \mathrm{~N}$ content of the glass fiber traps were measured with a Flash 2000 elemental analyzer coupled to a Delta $\mathrm{V}$ plus via the ConFlow interface (Thermo Fisher Scientific, Germany), at the Stable Isotope Facility at the Department of Biology, Lund, Sweden. Gross $\mathrm{N}$ mineralization, gross $\mathrm{NH}_{4}{ }^{+}$consumption, and gross nitrification rates were estimated according to the equations described by Bengtson and others (2005).

\section{Microbial Community Structure}

Microbial PLFA composition was determined from $0.5 \mathrm{~g}$ frozen subsamples, according to Frostegård and others (1993) with modifications (Nilsson and others 2007). An internal standard (methyl nonadecanoate fatty acid 19:0) was added before the methylation step for quantification. The derived fatty acid methyl esters (FAMEs) were quantified on a gas chromatograph with flame ionization detector. Bacterial- (i14:0, i15:0, a15:0, i16:0, $16: 1 \omega 9,16: 1 \omega 7$, 10Me16:0, i17:0, al7:0, 17:1 $\omega 8$, cyl7:0, br18:0, 10Me17:0, 18:1 $107,10 \mathrm{Mel} 18: 0$, and cy 19:0) and fungal-specific $(18: 2 \omega 6,9)$ PLFAs were used to estimate the relative abundance of these functional groups (Frostegård and Bååth 1996; Ruess and Chamberlain 2010). The sum total concentration of PLFAs (14:0, 15:0, 16:1 $\omega 5$, 16:0, 17:0, $18: 1 \omega 9,18: 1$, and 18:0, in addition to those listed above as bacterial and fungal biomarkers) was used as a measure of total microbial abundance.

\section{Data Analysis}

The effect of fertilization on soil physiochemical properties, microbial process rates, and microbial biomass variables was assessed by analysis of variance (ANOVA). Main and interactive effects of fertilization treatment and time on gross ecosystem productivity and ecosystem respiration were assessed by repeated-measures ANOVA. Prior to analysis, where necessary, dependent variables were first log-transformed to meet the assumptions (homogeneity of variance) of ANOVA. Significant differences were identified where $p<0.05$.

A principal component analysis (PCA) was also used to screen for treatment differences in the PLFA composition of the soil microbial community, using the relative abundances (mol.\%) of PLFAs, after standardizing to unit variance. The scores of the principal components were also subjected to ANOVA (as described above). All statistical analyses were performed using JMP 14.2 for Mac (SAS Institute).

\section{RESUlts}

\section{Soil Physiochemistry}

The fertilization treatment had no effect on soil water content, SOM, or soil pH (Table 1). There was also no difference in the concentration of ammonium and nitrate in control and fertilized soils (Table 1).

\section{Gross Ecosystem Productivity and Ecosystem Respiration}

Gross ecosystem productivity measured in 2014 was about four times higher in fertilized soils than in controls (Figure 1 A; $p<0.001$ ) and did not vary between the three measurement times, with no significant interaction between treatment and time. Ecosystem respiration was also higher in the fertilized soils (Figure 1B; $p<0.001$ ), but the effect 


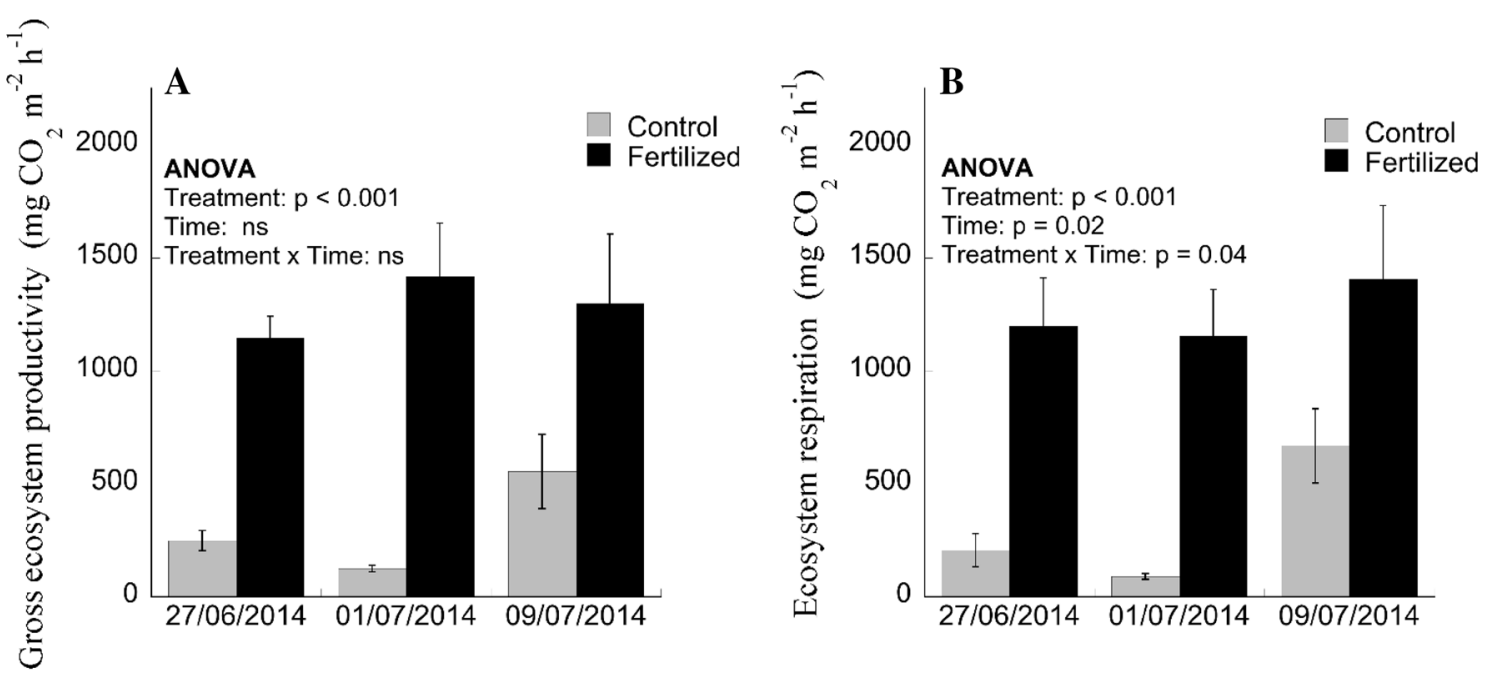

Figure 1. Rates of $(\mathbf{A})$ gross ecosystem productivity and $(\mathbf{B})$ ecosystem respiration in control and fertilized soils, measured in June-July 2014 after 26 years of nutrient (NPK) addition. Data represent mean \pm 1 SE $(n=6)$. Results from repeated measures ANOVA (ns = non-significant).

varied over time as shown by the significant 'Treatment $\mathrm{x}$ Time' interaction $(p=0.04)$.

\section{Bacterial and Fungal Growth Rates}

Rates of bacterial growth were about $70 \%$ higher in fertilized soils (Figure 2A; $p=0.01$ ), whereas there was no difference in fungal growth rates between control and fertilized soils (Figure 2B). Consequently, the ratio of fungal-to-bacterial growth was about $50 \%$ lower in fertilized soils compared to the control (Figure 2C; $p=0.03$ ).

\section{Soil C and N Mineralization}

Soil respiration (that is, soil $\mathrm{C}$ mineralization; $p=0.10)$ and gross $\mathrm{N}$ mineralization $(p=0.08)$ rates tended to be higher in fertilized soils com- pared to the control (Figure 3). This resulted in a C/ $\mathrm{N}$ ratio of mineralization of $36.1 \pm 5.8$ for the control soils and $27.6 \pm 5.7$ for the fertilized soils, ratios that were not statistically distinguishable. Gross $\mathrm{NH}_{4}{ }^{+}$consumption did not differ significantly between control and fertilized soils (Figure 4A), whereas gross nitrification was lower in the fertilized soils (Figure 4B; $p=0.04$ ).

\section{Microbial Biomass and Community Structure}

There was no difference in the total concentration of microbial PLFAs, bacterial PLFAs or fungal PLFAs in control and fertilized soils (Figure 5). There was also no effect of fertilization on the concentration
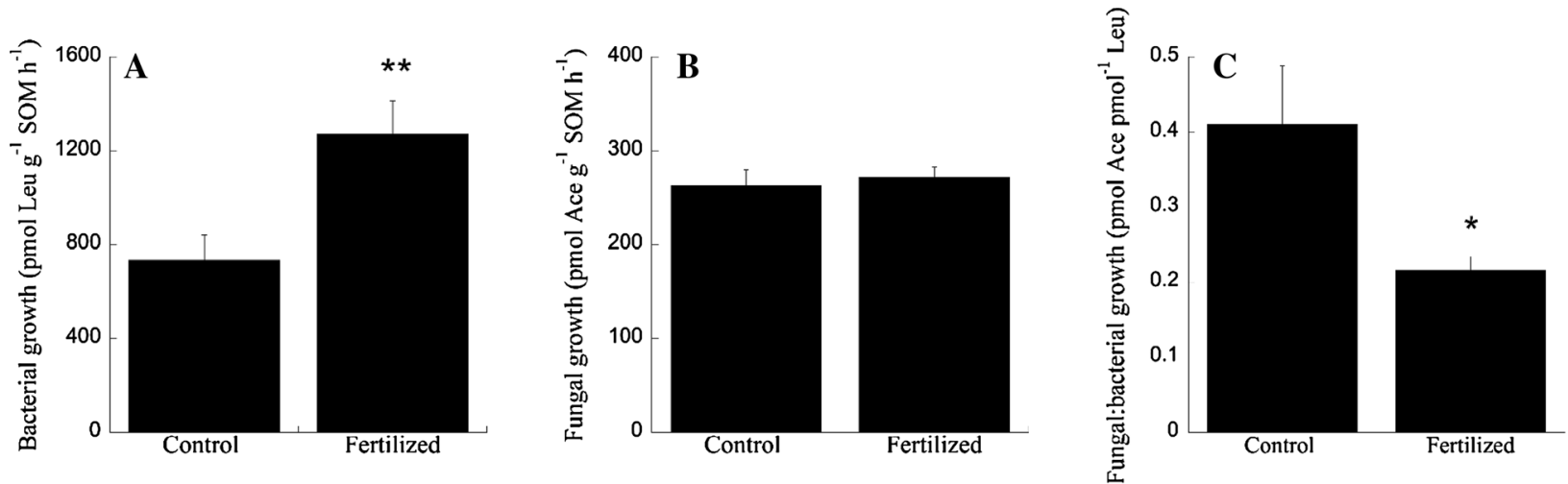

Figure 2. Rates of $(\mathbf{A})$ bacterial growth, $(\mathbf{B})$ fungal growth and $(\mathbf{C})$ the fungal-to-bacterial growth ratio in control and fertilized soils after 28 years of fertilization in a subarctic heath, Northern Sweden. Data represent mean \pm 1 SE $(n=6)$. Asterix denotes significant difference between control and fertilized soils according to ANOVA $\left({ }^{*} p<0.05, * * p<0.01\right)$. 


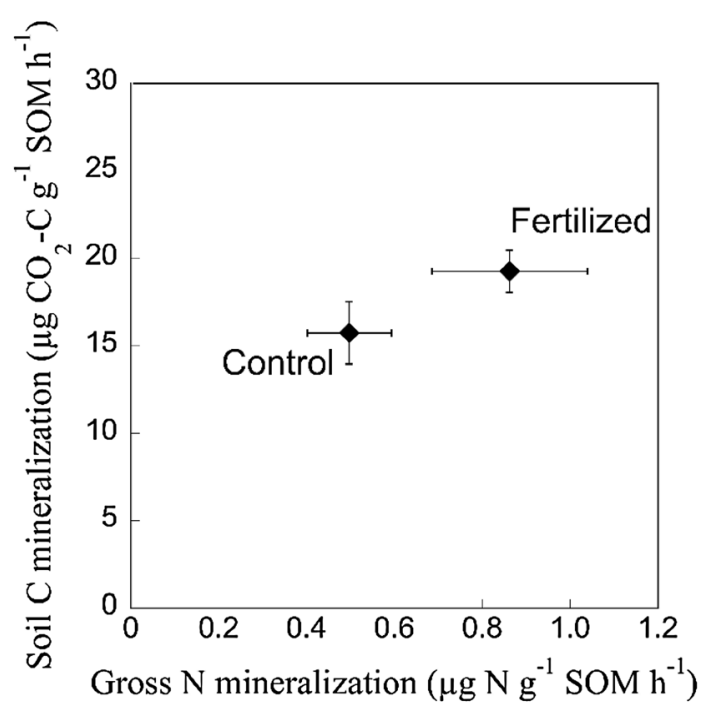

Figure 3. Rates of carbon and gross nitrogen mineralization in control and fertilized soils after 28 years of fertilization. Data represent mean $\pm 1 \mathrm{SE}$ $(n=6)$

of ergosterol or total microbial biomass determined by substrate-induced respiration (Table 1).

Fertilization had no significant effect on microbial PLFA composition, although there was a tendency for lower PC scores for control soils and higher PC scores for fertilized soils, along both PC1 and PC2 (Figure 6A). This trend appeared to be related to higher relative abundances of the fungal marker 18:2 $\omega 6,9$ toward negative variable loadings and higher relative abundances of PLFA markers associated with gram-positive bacteria (i15:0, al5:0, 16:0, il 7:0 and a17:0) toward positive variable loadings (Figure 6B). There was also a higher relative abundance of the gram-negative bacterial PLFA cy 17:0 toward positive PC scores and cy 19:0 toward negative scores.

\section{Discussion}

At the studied subarctic tundra site, soils have been fertilized with inorganic NPK for 28 years, with $\mathrm{N}$ addition equivalent to $100 \mathrm{~kg} \mathrm{~N} \mathrm{ha}^{-1} \mathrm{y}^{-1}$. This is a high $\mathrm{N}$ amendment compared to the annual $\mathrm{N}$ requirement for plant growth in tundra ecosystems (ca. 5-25 $\mathrm{kg} \mathrm{N} \mathrm{ha}^{-1} \mathrm{y}^{-1}$; Shaver and Chapin 1991; Jonasson and others 1999b; Sulman and others 2019). This $\mathrm{N}$ addition also far exceeds levels of atmospheric $\mathrm{N}$ deposition $\left(<5 \mathrm{~kg} \mathrm{ha}^{-1} \mathrm{y}^{-1}\right)$ in arctic and subarctic regions (Forsius and others 2010; Goth and others 2019). However, despite the long-term history of a substantially elevated $\mathrm{N}$ supply to the soils in our study, concentrations of $\mathrm{NH}_{4}{ }^{+}$and $\mathrm{NO}_{3}{ }^{-}$were not significantly higher in fertilized soils (Table 1). This suggests that the added $\mathrm{NH}_{4}-\mathrm{NO}_{3}$ was either rapidly immobilized by microorganisms (Jonasson and others 1996; Churchland and others 2010) or plants (Shaver and Jonasson 1999; Choudhary and others 2016), or lost from the system by volatilization, denitrification or leaching.

At the studied experimental site, higher plant productivity in response to the long-term fertilization has been well-documented (Jonasson and others 1999a; Graglia and others 2001; Illeris and others 2004; Campioli and others 2012; Ravn and others 2017). For example, in one of the most recent assessments, after 22 years of fertilization, vascular plant cover, shrub stem diameter, and fine
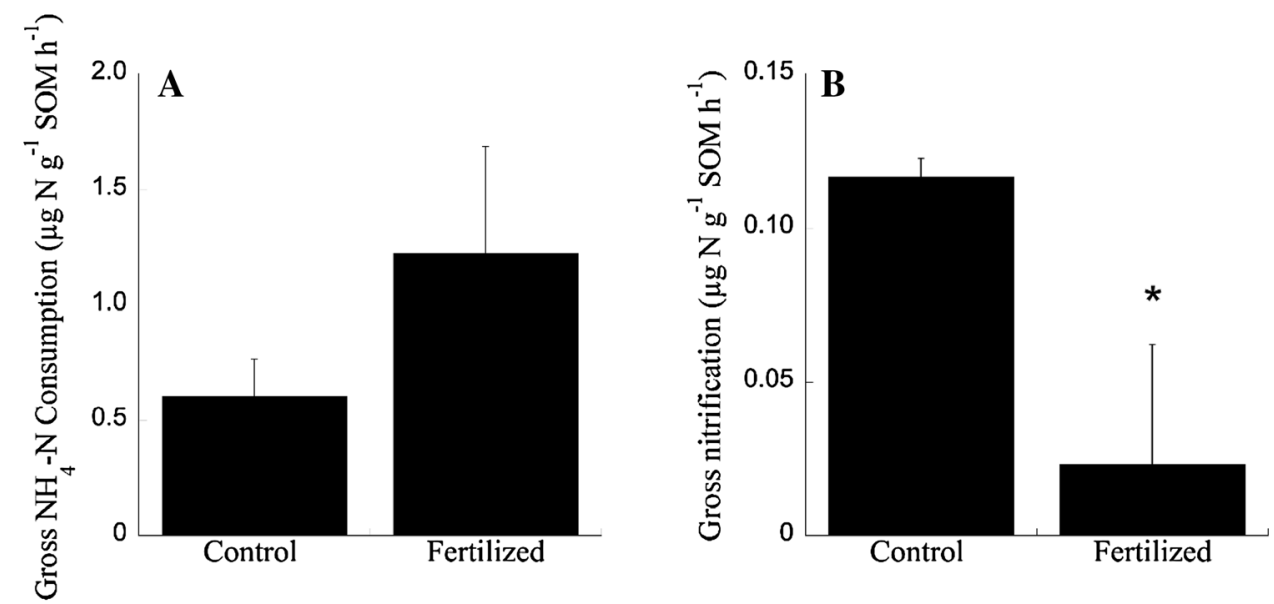

Figure 4. Rate of $(\mathbf{A})$ gross nitrogen consumption and $(\mathbf{B})$ gross nitrification in control and fertilized soils after 28 years of fertilization. Data represent mean \pm 1SE $(n=6)$. Asterix denotes significant difference between control and fertilized soils according to ANOVA (* $p<0.05)$. 

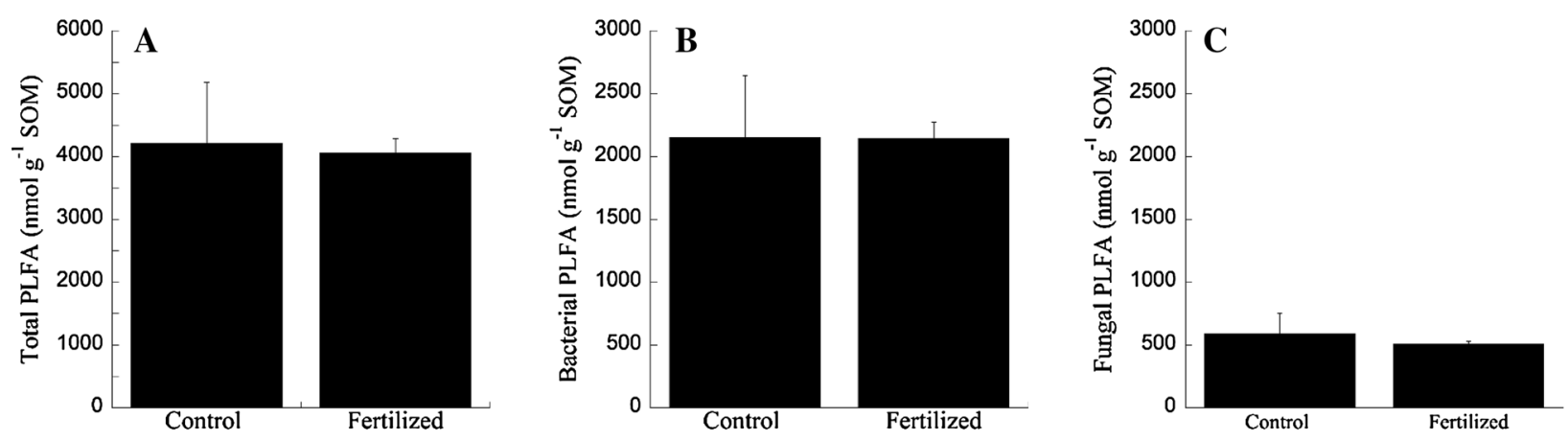

Figure 5. (A) Total microbial PLFA, (B) bacterial PLFA and (C) fungal PLFA concentrations in control and fertilized soils (reported per g soil organic matter; SOM) after 28 years of fertilization. Data represent mean \pm 1 SE $(n=6)$. Note different y-axis scales among panels.
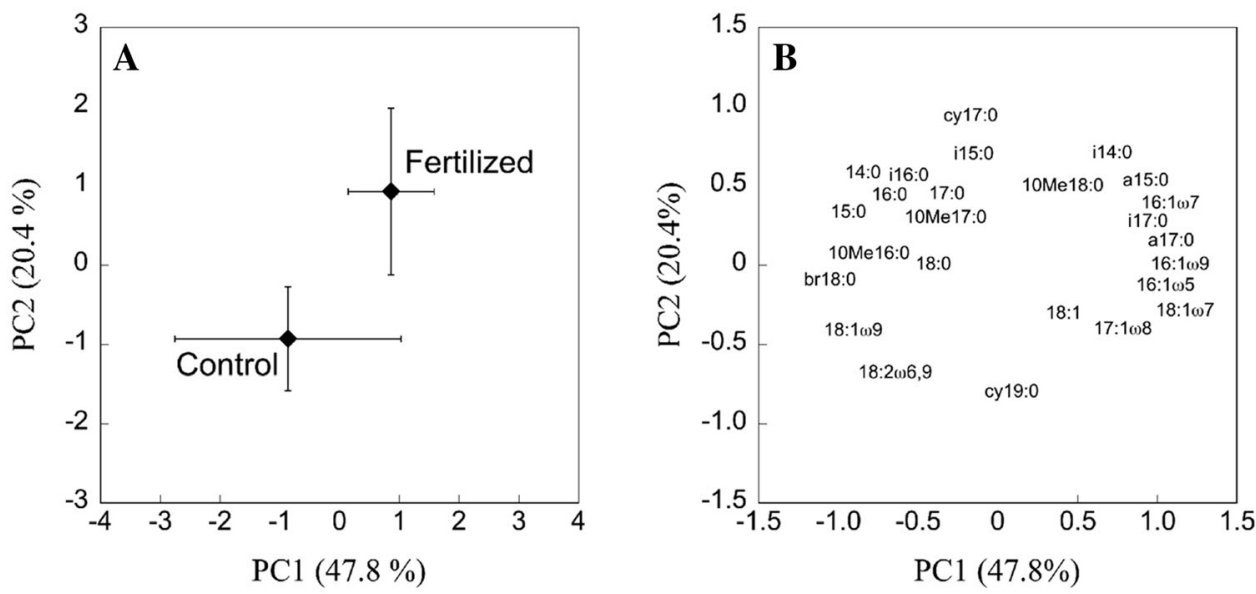

Figure 6. Microbial community structure in control and fertilized soils after 28 years of fertilization, according to a principal component analysis (PCA) of the PLFA composition (expressed as mol.\%). (A) Scores of the first two principal components, together explaining $68.2 \%$ variation (data represent mean $\pm 1 \mathrm{SE} ; n=6$ ). (B) Loadings of the first two components from the PCA of PLFA composition, showing the PLFA markers driving the separation among samples in A.

root biomass were all significantly higher in fertilized plots (Campioli and others 2012; Ravn and others 2017). We also found evidence for higher plant productivity with fertilization, as rates of gross ecosystem productivity measured after 26 years of fertilization were about four times higher in fertilized plots than controls (Figure 1A). We therefore expected that this increase in plant productivity would result in higher rates of microbial growth in fertilized soils. We also expected that fertilization would increase rates of $\mathrm{C}$ and gross $\mathrm{N}$ mineralization (Schimel and Bennett 2004). Surprisingly, despite the high nutrient loading rates and long-term duration of chronic annual additions, the only clear effect that we observed was higher bacterial growth in fertilized soils (Figure $2 \mathrm{~A}$ ), whereas there was no effect of fertilization on fungal growth (Figure 2B). This finding is in broad contrast with several studies where the addition of inorganic $\mathrm{N}$ in laboratory microcosm systems inhibited bacterial growth and tended to increase fungal growth (Rousk and Bååth 2007; Kristensen and others 2018; Silva-Sánchez and others 2019). This contrast between responses to inorganic $\mathrm{N}$-additions to soils in plant-free laboratory microcosms and responses to $\mathrm{N}$-fertilization in intact ecosystems studied in the field, suggests that the long-term fertilization in our study did not directly affect microbial growth rates and that the enhanced bacterial growth in fertilized soils was instead due to indirect effects driven by plants. There have been many reports of increased plant productivity with fertilization at the studied site (for example, Illeris and others 2004; Ravn and others 2017), with $35 \%$ higher vascular plant cover measured after 22 years of fertilization (Campioli and others 2012). More productive ecosystems are typically associated with more bacterially domi- 
nated energy channels (Moore and others 2003; Wardle and others 2004). This may explain our results, if increased inputs of labile plant-derived C in fertilized soils were used by bacteria, supporting higher bacterial growth rates. The $\mathrm{N}$ demand of bacteria is higher than fungal $\mathrm{N}$ demand (Strickland and Rousk 2010) and bacteria also exhibit stoichiometric homeostasis (Sterner and Elser 2002), which should result in a clear dependence of $\mathrm{N}$ immobilization on bacterial growth. Although there was a tendency for higher $\mathrm{N}$ consumption in fertilized soils when data were aggregated (Figure 4A), there was no significant relationship between bacterial growth rate and $\mathrm{N}$ consumption (data not shown; $p=0.23$ ).

We hypothesized that fertilization in this $\mathrm{N}$-poor ecosystem would increase rates of organic matter mineralization. We also expected that fertilization would increase $\mathrm{N}$ mineralization more than $\mathrm{C}$ mineralization (Schimel and Bennett 2004), resulting in a decrease in the $\mathrm{C} / \mathrm{N}$ ratio of mineralization, as previously observed following the addition of inorganic $\mathrm{N}$ to subarctic forest soils in microcosm systems (Kristensen and others 2018). Instead, we observed marginally higher rates of both $\mathrm{C}$ and $\mathrm{N}$ mineralization in fertilized soils (Figure 3), and although there was a trend for a decreased $\mathrm{C} / \mathrm{N}$ ratio of mineralization, the difference was not significant $(p=0.32)$. This finding is, however, consistent with our interpretation of higher bacterial growth rates in fertilized soils, driven by the higher primary productivity (Figure $1 \mathrm{~A}$ ) and thus more labile plant-derived $\mathrm{C}$ in these soils, resulting in higher respiration rates. Previous measurements of soil respiration in the field were found to be $133 \%$ higher with fertilization (Ravn and others 2017). Although root biomass was found to be almost twice as high in the fertilized soils, it is unlikely that this increase in respiration would be solely attributed to increased root respiration. The $\delta^{13} \mathrm{C}$ signal of respired $\mathrm{CO}_{2}$ was also found to be unaltered, suggesting that fertilization accelerated the whole $\mathrm{C}$ cycle, with no difference in the proportion of newly fixed plantderived $\mathrm{C}$ or older soil $\mathrm{C}$ that was mineralized. As such, in this case, Ravn and others (2017) concluded that the higher input of new plant $\mathrm{C}$ may have primed the decomposition of soil organic matter, explaining the unaltered $\delta^{13} \mathrm{C}$ signal. In contrast to the measurements of soil respiration in the field, rates of basal soil C mineralization in our study were only marginally higher in fertilized soils. This suggests that a flow of recently fixed C inputs from plants explained the enhanced respiration rates measured in the field observed by Ravn and others (2017). A similar finding was reported in response to long-term fertilization of Alaskan tundra soils, where there was no significant effect of fertilization on basal soil respiration, despite fertilization increasing ecosystem respiration by two to fourfold (Johnson and others 2000). Combined with these earlier results, our findings suggest that fertilization may drive changes in soil respiration in the field through short-lived effects on plant productivity (that is, via increased plantderived $\mathrm{C}$ inputs which are rapidly respired), rather than due to changes in the properties of soil organic matter or microbial community structure.

Some studies have reported higher gross nitrification rates following $\mathrm{N}$-fertilization (Hungate and others 1997; Barnard and others 2005). However, in our study, gross nitrification was significantly lower in fertilized soils (Figure 4B). Ammonia-oxidizing archaea have been shown to be more abundant and active than ammonia-oxidizing bacteria in both pristine and managed agricultural soils (Leininger and others 2006), as well as in high arctic tundra soils (Lamb and others 2011). It has also been shown that $\mathrm{N}$-fertilization reduces the relative abundance of archaeal ammonia oxidizers (Di and others 2009; Taylor and others 2012) along with their contribution to nitrification (Taylor and others 2010). This may explain our results. If ammonia-oxidizing archaea dominated nitrification in these subarctic soils, an archaeal inhibition by inorganic fertilizer addition (Taylor and others 2010) could result in reduced rates of nitrification.

The response of microbial biomass to long-term fertilization at the studied experimental site has been measured over time. In early assessments, after 5 and 6 years, there was no significant difference between microbial biomass $\mathrm{C}$ in control and fertilized soils (Jonasson and others 1999a; Ruess and others 1999). However, after 15 years of chronic fertilization, several metrics of microbial biomass were found to be higher, including $16 \%$ higher microbial PLFA concentrations in fertilized soils (Rinnan and others 2007). After 18 years of fertilization, the effect of fertilization increased further, with $31 \%$ higher microbial PLFAs in fertilized soils (Rinnan and others 2013). These later studies suggested that the effect of fertilization on microbial biomass may have taken time to manifest, potentially reflecting the long-term increase in plant productivity (Graglia and others 2001). As such, we expected to observe even more pronounced differences in microbial biomass after 28 years of fertilization. However, none of the measures of microbial biomass that we determined here were significantly different, or even suggested 
a trend for difference, between control and fertilized soils (Table 1 and Figure 5). One explanation for the inconsistent effects of fertilization on microbial biomass over time may be inter-annual differences in temperature and rainfall, if the effect of fertilization on plant productivity-and thus on microbial biomass-was amplified under more favorable environmental conditions. In this case, the years where microbial biomass was found to be higher in fertilized soils (that is, 2004 and 2006 after 15 and 18 years of fertilization) should coincide with years where temperatures were higher and there was more rainfall in the growing season preceding soil sampling. There is some evidence to support this explanation, as the average temperature during the growing season (June-August) was higher in 2004 and 2006 compared to 1993, 1994, and 2016 when the other assessments were conducted (Supplementary Table 1). Although total rainfall during the growing season varied considerably among years, this did not correspond to the observed differences in microbial biomass responses to fertilization over time (Supplementary Table 1). The time of soil-sampling may have also contributed to the inconsistent responses among studies, as the soils in our assessment were sampled in July 2016, whereas the soils from the 15- and 18-year assessments were sampled in mid- and late-August, respectively (Rinnan and others 2007, 2013). The later sampling times may have therefore increased the power to detect differences between control and fertilized soils, if the fertilization effects on plant productivity and thus microbial biomass, accrued over the growing season.

After 15 years of fertilization at the studied site, shifts in microbial community structure were reported (Rinnan and others 2007), whereas here, after 28 years of fertilization, microbial PLFA composition in control and fertilized soils were statistically indistinguishable (Figure 6A). The observed tendency for differences was, however, consistent with some results from the previous study, with a higher relative abundance of PLFA markers associated with gram-positive bacteria in the fertilized soils (Figure 6B). Our results also suggest a lower relative abundance of fungi in fertilized soils, which mirrors findings from a natural fertility gradient of boreal forest floors in Northern Sweden (Rousk and others 2013) and a long-term $\mathrm{N}$-fertilization experiment in the UK (Rousk and others 2011). In contrast with these studies, the addition of inorganic $\mathrm{N}$ to subarctic forest soils in the laboratory increased the abundance of the fungal PLFA marker (Kristensen and others 2018). Taken together, these results suggest that the direct effect of $\mathrm{N}$-fertilization may increase the relative abundance of fungi, and the lower relative abundance of fungi observed across natural fertility gradients (Rousk and others 2013) and in field-experiments (Rousk and others 2011 and our study) may be an indirect response driven by nutrient effects on plant productivity and/or plant community composition. Microbial community composition is often found to be responsive to changes in plant communities, likely due to the change in the physiochemical properties of litter and root inputs from different plants (Thoms and others 2010; Leff and others 2015; Hicks and others 2018). At the studied heath site, fertilization has reduced the abundance of mosses and lichens and increased the abundance of vascular plants (Graglia and others 2001; Campioli and others 2012). However, despite the increased abundance of vascular plants, there have been only subtle shifts in the relative abundance of functional types, with no consistent trajectory toward shrubs (Van Wijk and others 2003). The limited change in plant community composition in response to fertilization (that is, no large changes in the physiochemical properties of plant inputs) may therefore explain why more pronounced changes in microbial PLFA composition have not occurred.

Overall, despite the long-term history of substantially elevated nutrient supply to the soils in our study, we observed relatively minor effects on microbial activity. The most pronounced effect that we observed was a higher rate of bacterial growth in fertilized soils than controls, while fungal growth was unaffected. This resulted in a lower fungal-tobacterial growth ratio with fertilization, indicating a shift to more bacterially dominated decomposition in these soils. We also found that rates of soil C and $\mathrm{N}$ mineralization were only marginally higher in fertilized soils than controls. This was in clear contrast to measurements of soil respiration made in situ at the studied site, where fertilization increased the $\mathrm{CO}_{2}$ efflux from soils by $133 \%$ (Ravn and others 2017). Combined with these earlier findings, our results suggest that microbial responses to long-term fertilization in these subarctic tundra soils are likely driven by the increased flow of labile plant-derived C-due to stimulated plant productivity-rather than due to direct fertilization effects on the microbial community or changes in soil physiochemistry. This suggests that plant responses to elevated nutrient availability, as a result of future climate warming in high-latitude soils, will be crucial in determining the response of soil microbial activities belowground. 


\section{ACKNOWLEDGEMENTS}

Open access funding was provided by Lund University. We thank Anders Michelsen for providing access to the field experiment, Pernille Ahlefeldt Wetterberg for field assistance, Eva Berglund for laboratory assistance and the Abisko Scientific Research Station (ANS) for providing logistical support. This study was supported by grants from the Crafoord Foundation (Grant No. 20150561), the Swedish Research Council Formas (Grant No. 2018-01315), the Swedish Research Council Vetenskapsrådet (Grant No. 2015-04942), and the Knut and Alice Wallenberg Foundation (Grant No. KAW 2017.0171). The Danish National Research Foundation supported the activities within the CENPERM (CENPERM DNRF100). The research is a contribution to the strategic research area Biodiversity and Ecosystems in a Changing Climate (BECC) at Lund University.

\section{OPEN ACCESS}

This article is distributed under the terms of the Creative Commons Attribution 4.0 International License (http://creativecommons.org/licenses/by/4 $.0 /$ ), which permits unrestricted use, distribution, and reproduction in any medium, provided you give appropriate credit to the original author(s) and the source, provide a link to the Creative Commons license, and indicate if changes were made.

\section{REFERENCES}

Abisko Scientific Research Station. 2016. Temperature and precipitation data 1913-2015. Abisko Sci. Res. Station, Polarforskningssektretariatet. Available from: http://polar.se/ab isko.

Anderson JPE, Domsch KH. 1978. A physiological method for the quantitative measurement of microbial biomass in soils. Soil Biol. Biochem. 10:215-21.

Atkin OK. 1996. Reassessing the nitrogen relations of Arctic plants: a mini-review. Plant Cell Environ. 19:695-704.

Barnard R, Leadley PW, Hungate BA. 2005. Global change, nitrification, and denitrification: a review. Global Biogeochem. Cycles 19:1007.

Bååth E. 2001. Estimation of fungal growth rates in soil using ${ }^{14} \mathrm{C}$-acetate incorporation into ergosterol. Soil Biol. Biochem. 33:2011-18.

Bååth E, Pettersson M, Söderberg KH. 2001. Adaptation of a rapid and economical microcentrifugation method to measure thymidine and leucine incorporation by soil bacteria. Soil Biol. Biochem. 33:1571-4.

Bengtson P, Falkengren-Grerup U, Bengtsson G. 2005. Relieving substrate limitation soil moisture and temperature determine gross $\mathrm{N}$ transformation rates. Oikos 111:81-90.

Buckeridge KM, Cen YP, Layzell DB, Grogan P. 2010. Soil biogeochemistry during the early spring in low arctic mesic tundra and the impacts of deepened snow and enhanced nitrogen availability. Biogeochemistry 99:127-41.

Campioli M, Leblans N, Michelsen A. 2012. Twenty-two years of warming, fertilisation and shading of subarctic heath shrubs promote secondary growth and plasticity but not primary growth. PloS ONE 7:e34842.

Churchland C, Mayo-Bruinsma L, Ronson A, Grogan P. 2010. Soil microbial and plant community responses to single large carbon and nitrogen additions in low arctic tundra. Plant Soil 334:409-21.

Choudhary S, Blaud A, Osborn AM, Press MC, Phoenix GK. 2016. Nitrogen accumulation and partitioning in a High Arctic tundra ecosystem from extreme atmospheric $\mathrm{N}$ deposition events. Sci. Total Environ. 554:303-10.

Chu H, Grogan P. 2010. Soil microbial biomass, nutrient availability and nitrogenmineralization potential among vegetation-types in a low arctic tundra landscape. Plant and Soil 329:411-20.

Di HJ, Cameron KC, Shen JP, Winefield CS, O'Callaghan M, Bowatte S, He JZ. 2009. Nitrification driven by bacteria and not archaea in nitrogen-rich grassland soils. Nat. Geosci. 2:621-4.

Ehtesham E, Bengtson P. 2017. Decoupling of soil carbon and nitrogen turnover partlyexplains increased net ecosystem production in response to nitrogen fertilization. Sci. Rep. 7:46286.

Fog K. 1988. The effect of added nitrogen on the rate of decomposition of organic matter. Biol. Rev. 63:433-62.

Forsius M, Posch M, Aherne J, Reinds GJ, Christensen J, Hole L. 2010. Assessing the impacts of long-range sulfur and nitrogen deposition on arctic and sub-arctic ecosystems. Ambio 39:136-47.

Frostegård Å, Tunlid A, Bååth E. 1993. Phospholipid fatty acid composition, biomass, and activity of microbial communities from two soil types experimentally exposed to different heavy metals. Appl. Environ. Microbiol. 59:3605-17.

Frostegård A, Bååth E. 1996. The use of phospholipid fatty acid analysis to estimate bacterial and fungal biomass in soil. Biol. Fertil. Soils 22:59-65.

Goth A, Michelsen A, Rousk K. 2019. Railroad derived nitrogen and heavy metal pollution does not affect nitrogen fixation associated with mosses and lichens at a tundra site in Northern Sweden. Environ. Pollut. 247:857-65.

Gough L, Hobbie SE. 2003. Responses of moist non-acidic arctic tundra to altered environment: productivity, biomass, and species richness. Oikos 1031:204-16.

Gough L, Wookey PA, Shaver GR. 2002. Dry heath arctic tundra responses to long term nutrient and light manipulation. Arct. Antarct. Alp. Res. 34:211-18.

Graglia E, Jonasson S, Michelsen A, Schmidt IK, Havström M, Gustavsson L. 2001. Effects of environmental perturbations on abundance of subarctic plants after three, seven and ten years of treatments. Ecography 24:5-12.

Hart SC, Nason G, Myrold DD, Perry DA. 1994. Dynamics of gross nitrogen transformations in an old-growth forest: the carbon connection. Ecology 75:880-91.

Havström M, Callaghan TV, Jonasson S. 1993. Differential growth responses of Cassiope tetragona, an arctic dwarfshrub, to environmental perturbations among three contrasting high-and subarctic sites. Oikos 66:389-402.

Hicks LC, Rahman MM, Carnol M, Verheyen K, Rousk J. 2018. The legacy of mixed planting and precipitation reduction 
treatments on soil microbial activity, biomass and community composition in a young tree plantation. Soil Biol. Biochem. 124:227-35.

Hungate BA, Lund CP, Pearson HL, Chapin FS. 1997. Elevated $\mathrm{CO}_{2}$ and nutrient addition after soil $\mathrm{N}$ cycling and $\mathrm{N}$ trace gas fluxes with early season wet-up in a California annual grassland. Biogeochemistry 37:89-109.

Hobbie SE. 1996. Temperature and plant species control over litter decomposition in Alaskan tundra. Ecol. Monogr. 66:503-22.

Hobbie SE, Nadelhoffer KJ, Högberg P. 2002. A synthesis: the role of nutrients as constraints on carbon balances in boreal and arctic regions. Plant Soil 242:163-70.

IAEA Training Course Series. 2001. Use of isotope and radiation methods in soil and water management and crop nutrition. Vienna: IAEA.

Illeris L, König SM, Grogan P, Jonasson S, Michelsen A, RoPoulsen H. 2004. Growing-season carbon dioxide flux in a dry subarctic heath: responses to long-term manipulations. Arct. Antarct. Alp. Res. 36:456-63.

IUSS Working Group WRB. 2006. World reference base for soil resources 2006. World Soil Resources Reports 103.

Jenny H. 1980. The soil resource: origin and behavior ecological studies no. 37. New York: Springer.

Johnson LC, Shaver GR, Cades DH, Rastetter E, Nadelhoffer K, Giblin A, Laundre J, Stanley A. 2000. Plant carbon-nutrient interactions control $\mathrm{CO}_{2}$ exchange in Alaskan wet sedge tundra ecosystems. Ecology 81:453-69.

Jonasson S, Michelsen A, Schmidt IK, Nielsen EV, Callaghan TV. 1996. Microbial biomass C, N and P in two arctic soils and responses to addition of NPK fertilizer and sugar: implications for plant nutrient uptake. Oecologia 106:507-15.

Jonasson S, Michelsen A, Schmidt IK, Nielsen EV. 1999a. Responses in microbes and plants to changed temperature, nutrient, and light regimes in the arctic. Ecology 80:1828-43.

Jonasson S, Michelsen A, Schmidt IK. 1999b. Coupling of nutrient cycling and carbon dynamics in the Arctic, integration of soil microbial and plant processes. Appl. Soil. Ecol. 11:135-46.

Kristensen JA, Metcalfe DB, Rousk J. 2018. The biogeochemical consequences of litter transformation by insect herbivory in the Subarctic: a microcosm simulation experiment. Biogeochemistry 138:323-36.

Lamb EG, Han S, Lanoil BD, Henry GH, Brummell ME, Banerjee S, Siciliano SD. 2011. A High Arctic soil ecosystem resists longterm environmental manipulations. Global Change Biol. $17: 3187-94$.

Leininger S, Urich T, Schloter M, Schwark L, Qi J, Nicol GW, Prosser JI, Schuster SC, Schleper C. 2006. Archaea predominate among ammonia-oxidizing prokaryotes in soils. Nature 442:806-9.

Leff JW, Jones SE, Prober SM, Barberán A, Borer ET, Firn JL, Harpole WS, Hobbie SE, Hofmockel KS, Knops JM, McCulley RL. 2015. Consistent responses of soil microbial communities to elevated nutrient inputs in grasslands across the globe. Proc. Natl. Acad. Sci. 112:10967-72.

Mack MC, Schuur EA, Bret-Harte MS, Shaver GR, Chapin FSIII. 2004. Ecosystem carbon storage in arctic tundra reduced by long-term nutrient fertilization. Nature 431:440-3.

McLaren JR, Buckeridge KM. 2019. Decoupled above-and belowground responses to multidecadal nitrogen and phos- phorus amendments in two tundra ecosystems. Ecosphere 10:e02735.

Michelsen A, Jonasson S, Sleep D, Havström M, Callaghan TV. 1996. Shoot biomass, $\delta^{13} \mathrm{C}$, nitrogen and chlorophyll responses of two arctic dwarf shrubs to in situ shading, nutrient application and warming simulating climatic change. Oecologia 105:1-12.

Moore JC, McCann K, Setälä H, De Ruiter PC. 2003. Top-down is bottom-up: does predation in the rhizosphere regulate aboveground dynamics? Ecology 84:846-57.

Newell SY, Fallon RD. 1991. Toward a method for measuring instantaneous fungal growth rates in field samples. Ecology $72: 1547-59$

Nilsson LO, Bååth E, Falkengren-Grerup U, Wallander H. 2007. Growth of ectomycorrhizal mycelia and composition of soil microbial communities in oak forest soils along a nitrogen deposition gradient. Oecologia 153:375-84.

Pregitzer KS, Burton AJ, Zak DR, Talhelm AF. 2008. Simulated chronic nitrogen deposition increases carbon storage in Northern Temperate forests. Global Change Biol. 14:142-53.

Ramirez KS, Craine JM, Fierer N. 2010. Nitrogen fertilization inhibits soil microbial respiration regardless of the form of nitrogen applied. Soil Biol. Biochem. 42:2336-8.

Ravn NR, Ambus P, Michelsen A. 2017. Impact of decade-long warming, nutrient addition and shading on emission and carbon isotopic composition of $\mathrm{CO}_{2}$ from two subarctic dwarf shrub heaths. Soil Biol. Biochem. 111:15-24.

Rinnan R, Michelsen A, Bååth E, Jonasson S. 2007. Fifteen years of climate change manipulations alter soil microbial communities in a subarctic heath ecosystem. Global Change Biol. 13:28-39.

Rinnan R, Michelsen A, Bååth E. 2013. Fungi benefit from two decades of increased nutrient availability in tundra heath soil. PLOS ONE 8:e56532.

Rousk J, Bååth E. 2007. Fungal biomass production and turnover in soil estimated using the acetate-in-ergosterol technique. Soil Biol. Biochem. 39:2173-7.

Rousk J, Brookes PC, Bååth E. 2009. Contrasting soil pH effects on fungal and bacterial growth suggest functional redundancy in carbon mineralization. Appl. Environ. Microbiol. 75:158996.

Rousk J, Brookes PC, Bååth E. 2011. Fungal and bacterial growth responses to $\mathrm{N}$ fertilization and $\mathrm{pH}$ in the 150 -year 'Park Grass' UK grassland experiment. FEMS Microbiol. Ecol. 76:89-99.

Rousk K, Rousk J, Jones DL, Zackrisson O, DeLuca TH. 2013. Feather moss nitrogen acquisition across natural fertility gradients in boreal forests. Soil Biol. Biochem. 61:86-95.

Rousk K, Michelsen A, Rousk J. 2016. Microbial control of soil organic matter mineralization responses to labile carbon in subarctic climate change treatments. Global Change Biol. 22:4150-61.

Ruess L, Michelsen A, Schmidt IK, Jonasson S. 1999. Simulated climate change affecting microorganisms, nematode density and biodiversity in subarctic soils. Plant Soil 212:63-73.

Ruess L, Chamberlain PM. 2010. The fat that matters: soil food web analysis using fatty acids and their carbon stable isotope signature. Soil Biol. Biochem. 42:1898-910.

Schimel JP, Bennett J. 2004. Nitrogen mineralization: challenges of a changing paradigm. Ecology 85:591-602. 
Shaver GR, Chapin FSIII. 1980. Response to fertilization by various plant growth forms in an Alaskan tundra: nutrient accumulation and growth. Ecology 61:662-75.

Shaver GR, Chapin FSIII. 1991. Production: biomass relationships and element cycling in contrasting arctic vegetation types. Ecol. Monogr. 61:1-31.

Shaver GR, Jonasson S. 1999. Response of Arctic ecosystems to climate change: results of long-term field experiments in Sweden and Alaska. Polar Res. 18:245-52.

Silva-Sánchez A, Soares M, Rousk J. 2019. Testing the dependence of microbial growth and carbon use efficiency on nitrogen availability, $\mathrm{pH}$, and organic matter quality. Soil Biol. Biochem. 134:25-35.

Sistla SA, Asao S, Schimel JP. 2012. Detecting microbial N-limitation in tussock tundra soil: implications for Arctic soil organic carbon cycling. Soil Biol. Biochem. 55:78-84.

Sorensen PL, Lett S, Michelsen A. 2012. Moss-specific changes in nitrogen fixation following two decades of warming, shading, and fertilizer addition. Plant Ecol. 213:695-706.

Sterner RW, Elser JJ. 2002. Ecological stoichiometry: the biology of elements from molecules to the biosphere. Princeton: Princeton University Press.

Strickland MS, Rousk J. 2010. Considering fungal: bacterial dominance in soils methods, controls, and ecosystem implications. Soil Biol. Biochem. 42:1385-95.

Sulman BN, Shevliakova E, Brzostek ER, Kivlin SN, Malyshev S, Menge DN, Zhang X. 2019. Diverse mycorrhizal associations enhance terrestrial C storage in a global model. Global Biogeochem. Cycles 33:501-23.

Taylor AE, Zeglin LH, Dooley S, Myrold DD, Bottomley PJ. 2010. Evidence for different contributions of archaea and bacteria to the ammonia-oxidizing potential of diverse Oregon soils. Appl. Environ. Microbiol. 76:7691-8.

Taylor AE, Zeglin LH, Wanzek TA, Myrold DD, Bottomley PJ. 2012. Dynamics of ammonia-oxidizing archaea and bacteria populations and contributions to soil nitrification potentials. ISME J. 6:2024.

Thoms C, Gattinger A, Jacob M, Thomas FM, Gleixner G. 2010. Direct and indirect effects of tree diversity drive soil microbial diversity in temperate deciduous forest. Soil Biol. Biochem. 42:1558-65.

Treseder KK. 2008. Nitrogen additions and microbial biomass: A meta-analysis of ecosystem studies. Ecol. Lett. 11:1111-20.

Van Wijk MT, Clemmensen KE, Shaver GR, Williams M, Callaghan TV, Chapin FSIII, Cornelissen JHC, Gough L, Hobbie SE, Jonasson S, Lee JA. 2003. Long-term ecosystem level experiments at Toolik Lake, Alaska, and at Abisko, Northern Sweden: generalizations and differences in ecosystem and plant type responses to global change. Global Change Biol. 10:105-23.

Wardle DA. 2002. Communities and ecosystems: linking the aboveground and belowground components. Princeton: Princeton University Press.

Wardle DA, Bardgett RD, Klironomos JN, Setälä H, Van Der Putten WH, Wall DH. 2004. Ecological linkages between aboveground and belowground biota. Science 304:1629-33.

Weintraub MN, Schimel JP. 2003. Interactions between carbon and nitrogen mineralization and soil organic matter chemistry in arctic tundra soils. Ecosystems 6:129-43.

Whalen ED, Smith RG, Grandy AS, Frey SD. 2018. Manganese limitation as a mechanism for reduced decomposition in soils under atmospheric nitrogen deposition. Soil Biol. Biochem. 127:252-63.

Wild B, Schnecker J, Knoltsch A, Takriti M, Mooshammer M, Gentsch N, Mikutta R, Alves RJE, Gittel A, Lashchinskiy N, Richter A. 2015. Microbial nitrogen dynamics in organic and mineral soil horizons along a latitudinal transect in western Siberia. Global Biogeochem. Cycles 29:567-82. 